\title{
OXYTOCIN ADMINISTRATION IMPROVES MEMORY, ANXIETY AND SOME OXIDATIVE STRESS PARAMETERS IN A METHIONINE- INDUCED RAT MODEL OF SCHIZOPHRENIA
}

\author{
MANUELA PĂDURARIU ${ }^{1}$, MIRUNA BALMUȘ ${ }^{2}$, ALIN CIOBÎCĂ ${ }^{2,3}$, RADU LEFTER $^{2,4}$, \\ SABINA COJOCARU ${ }^{2}$, IULIA ANTIOCH ${ }^{2}$, HARQUIN FOYET $^{5}$, ROMEO DOBRIN ${ }^{1}$, DANIELA \\ CARMEN ABABEI $^{1 *}$, VERONICA BILD $^{1}$
}

1“Grigore T. Popa” University of Medicine and Pharmacy, 16 Universității Street, 700115, Iași, Romania

2 "Alexandru Ioan Cuza” University, Faculty of Biology, Department of Research, 11 Carol I Boulevard, Iași, Romania

${ }^{3}$ Academy of Romanian Scientists, 54 Splaiul Independenței Street, District 5, 050094, Bucharest, Romania

${ }^{4}$ Romanian Academy, Center of Biomedical Research, 8 Carol I Boulevard, Iași, Romania

${ }^{5}$ University of Maroua, Faculty of Science, Department of Biological Sciences, P.O. Box 814, Maroua, Cameroon

*corresponding author: dana.ababei@gmail.com

Manuscript received: January 2018

\begin{abstract}
Lately there is an increased interest in understanding the possible relevance of oxytocin administration in the schizophrenic pathology. Also, currently in the literature there are models of schizophrenia, such as the one based on methionine administration, capable of replicating both positive and negative specific symptoms of schizophrenia, as well as the cognitive deficits from this disorder, which are believed to affect up to $75 \%$ of patients diagnosed with schizophrenia. In this context, in the present paper we were interested in preliminary revealing the effects of intraperitoneally oxytocin administration for 9 days, in a new approach, in a rat model of schizophrenia generated by administration of methionine for 2 weeks, on the memory and anxiety deficits induced by methionine administration (as studied in Y maze and elevated plus maze tasks), as well as on the oxidative stress markers (two antioxidant enzymes: superoxide dismutase-SOD and glutathione peroxidase-GPX, and the lipid peroxidation biomarker, malondialdehyde-MDA) from the temporal lobe. Our results showed some ameliorative effects of oxytocin administration on the immediate spatial memory (increased spontaneous alternation in Y maze) and anxiety-induced deficits (oxytocin increased the time spent in the open arms of the elevated plus maze) generated by the methionine-induced rat model of schizophrenia. Even more, oxytocin administration exerted some antioxidant effects in this model, as demonstrated by increased specific activity of GPX and reduced levels of MDA from the temporal lobe in the methionine + oxytocin group, as compared to the methionine group of rats. However, no significant modifications in SOD specific activity were found. This could have further relevance for the mechanistic behind the administration of oxytocin in the schizophrenia pathophysiology.
\end{abstract}

\section{Rezumat}

În ultimul timp există un interes crescut în ceea ce privește posibila relevanță a administrării de oxitocină în patologia schizofrenică. De asemenea, la ora actuală în literatură se cunosc modele animale de schizofrenie, cum ar fi modelul bazat pe administrarea de metionină, prin care se pot reproduce simptomele pozitive și negative specifice schizofreniei, precum și deficitele cognitive ale acestei tulburări, despre care se cunoaște că afectează până la 75\% dintre pacienții diagnosticați cu schizofrenie. În acest context, în lucrarea de față am realizat o evaluare preliminară a efectelor administrării intraperitoneale de oxitocină timp de 9 zile printr-o abordare nouă, pe un model de schizofrenie la şobolan generat prin injectarea de metionină timp de 2 săptămâni. Au fost urmărite modificările parametrilor de memorie și anxietate induse prin administrarea de metionină (studiate în testul labirintului Y și labirintului elevated-plus), precum şi dinamica biomarkerilor de stres oxidativ (două enzime antioxidante: superoxid dismutaza-SOD şi glutation-peroxidaza-GPX, precum şi un biomarker de peroxidare lipidică, malondialdehida-MDA) la nivelul lobului temporal. Rezultatele obținute scot în evidență o serie de efecte ameliorative ale administrării oxitocinei asupra memoriei spațiale imediate (prin creșterea indicelui de alternanța spontană în labirintul Y) şi asupra stărilor de anxietate (creșterea timpului petrecut în brațele deschise ale labirintului elevated-plus), generate în urma tratamentului cu metionină. Mai mult, administrarea de oxitocină a exercitat anumite efecte antioxidante la acest model, aspect demonstrat prin creșterea activității specifice a GPX și reducerea nivelului de MDA din lobul temporal la grupul tratat cu oxitocină. Pe de altă parte, nu s-au găsit modificări semnificative ale activității specific a SOD. Aceste rezultate ar putea avea o relevanţă deosebită în elucidarea căilor specifice de acțiune ale oxitocinei în patofiziologia schizofreniei.

Keywords: oxytocin, schizophrenia, rat, methionine, memory, anxiety, oxidative stress

\section{Introduction}

Currently there is an increased interest in generating and studying rodent models of neuropsychiatric disorders, as well as preliminary testing in these models the variety of new drugs proposed as possible treatments. Thus, most of these rat models are 
FARMACIA, 2018, Vol. 66, 3

based on various genetic manipulations [1], neurosurgery methods [2], behavioural [3] and pharmacological alterations [4].

Regarding schizophrenia, the most important rodent models are generated by the administration of ketamine, phencyclidine or methionine. Still, it is virtually impossible to perfectly replicate in rodents or any other animal model the complex human schizophrenic symptomatology (a fact which is also available for all the other neuropsychiatric disorders mentioned above), mainly characterized by strong gross distortion from reality, on the level of thinking, feeling and general behaviour [5].

However, the use of these rat models has a clear list of advantages, including the fact that they are easy to obtain, maintain and handle, with increased reproductive rates, and exhibiting in the same time most of the general physiological and anatomical similarities to humans [6].

In fact, currently, to our knowledge, there are 3 main reviews in the literature describing the animal models of schizophrenia. In the Marcotte study [7], the authors are only describing the pharmacological methods (based on the manipulation of the main neurotransmitters implicated such dopamine, glutamate, serotonin or GABA) and the lesioning models, related to the neurodegenerative part of schizophrenia (e.g. prefrontal cortex or intracerebroventricular kainic acid administration) $v s$. its neurodevelopmental nature (our group also recently published a report demonstrating a Purkinje cells pathology in schizophrenia, though a morphometric approach [8]), while Jones et al., in a slightly more complex approach [9], described the neurodevelopmental models (mainly gestational methylazoxymethanol and post-weaning social isolation), the pharmacological ones (e.g. those related to the administration of amphetamines or $\mathrm{N}$ methyl-D-aspartate (NMDA) antagonists such as ketamine and especially phencyclidine), the lesioning models (in this case related to neonatal ventral hippocampal area) or the genetic ones (those related to disrupted in schizophrenia 1 (DISC1) gene, neuregulin, dysbindin or reelin). In addition, the Wilson report [10] is summarizing all these aforementioned aspects, focusing also on the most important 3 requirements for a good animal model, represented by the face validity (the closeness to the human symptoms), the construct validity (replicating more or less the same mechanistic of schizophrenia) and finally the predictive validity (response to treatments used in human patients for that specific disorder - in this case the antipsychotics) $[10,11]$.

What is important to mention in the context of our present paper is the fact that in 2015 the Wang group [12] described a very simple and reliable rodent model of schizophrenia, based on methionine administration (the classical essential amino acid), which they reported that could actually replicate in a very complex and integrated manner 3 fundamental symptoms of schizophrenia: the positive symptoms, the negative ones, as well as the cognitive deficits associated with this disorder, as it is lately believed that around $75 \%$ of patients diagnosed with schizophrenia are showing significant cognitive impairments such as memory loss, affected attention, motor skills, decreased executive function and intelligence [13].

In this way, the aforementioned authors demonstrated that 7 days of methionine administration results in the aforementioned manifestation in mice, as demonstrated in specific rodent behavioural testing such as locomotion test chamber, 3-chambered social interaction test, forced swimming test, pre-pulse inhibition, novel object recognition, inhibitory avoidance or stereotypical behaviour determination [12].

Another important aspect in the schizophrenic pathology is represented by the modifications of the oxidative stress status, as our group also previously demonstrated in medicated patients with schizophrenia $[14,15]$ or by showing significant correlations between some main oxidative stress markers and specific scales for schizophrenia such as AIMS (Abnormal Involuntary Movement Scale) and PANSS (Positive and Negative Syndrome Scale) [16]. These aspects were also confirmed by other research groups [17, 18], with additional reports describing the effects of some antioxidant extracts (e.g. Ginkgo biloba etc.) as an additive treatment in patients with schizophrenia $[19,20]$.

Regarding oxytocin, it is a molecule well known for its classical effects in parturition and lactation [21]. However, in the last couple of years there is an increased interest for understanding the effects of oxytocin in some neuropsychiatric manifestations which include a social component, such as autism [22], anxiety [23], depression [24, 25] and schizophrenia [26].

In fact, when it comes to the effects of oxytocin administration in schizophrenia, there are more than 17 important papers in this area of research on Medline only between 2016 to 2017 [27-43], however with some controversial results describing for example either no evidence for a possible efficacy of intranasal oxytocin administration in the negative symptoms of schizophrenia or its associated cognitive deficits [27] or no effects at all on the so-called "jumping to conclusions" behaviour in schizophrenia [31], while other reports are stating that just onesingle dose of oxytocin (24 international units-IU) nasal spray could significantly improve higher-order cognition in the schizophrenic pathology [26]. Still, most of the studies and meta-analysis performed in the last 2 years are describing mixed effects of oxytocin administration in schizophrenia [29], such as an improvement in the high-level social cognition, but no effects on commune social cognition and neuro- 
cognition in general [28] or additional metaanalyses which are concluding that oxytocin could help in high-level social cognition, such as mentalizing and theory of mind-related manifestation, but with no effects on the low-level social cognition (e.g. cue perception) [30].

What is also very important in the context of the present paper is the fact that it was recently showed that there is an important correlation between the methylation of the specific oxytocin receptor and the cognitive deficits from the schizophrenic pathology [34].

Even more, the effects of oxytocin administration on the oxidative stress status are controversial, with reports stating its antioxidant and protective effects $[44,45]$, while other authors described clear prooxidant actions for oxytocin [46].

In this context, in the present paper we were interested in assessing the preliminary effects of intraperitoneal oxytocin administration for 9 days, in a new approach, in a rat model of schizophrenia generated by the administration of methionine for 2 weeks, on the memory and anxiety deficits induced by methionine administration (as studied in $\mathrm{Y}$ maze and elevated plus maze tasks), as well as on the oxidative stress biomarkers (two antioxidant enzymes: SOD (superoxide dismutase) and GPX (glutathione peroxidase), and the lipid peroxidation biomarker, MDA (malondialdehyde) from the temporal lobe, the most sensitive area of the brain to the modifications of the oxidative stress status [49].

\section{Materials and Methods}

\section{Animals}

Male Wistar $(\mathrm{n}=21)$ rats, weighing $200-250 \mathrm{~g}$ at the beginning of the experiment, were kept in a room with controlled temperature $\left(22^{\circ} \mathrm{C}\right)$ and a $12: 12-\mathrm{h}$ light/dark cycle (starting at 08:00 h), with food and water ad libitum and divided in 3 groups: control, methionine and methionine + oxytocin group $(n=7$, for each group).

The animals were treated in accordance with the guidelines of animal bioethics from the Act on Animal Experimentation and Animal Health and Welfare Act from Romania and all procedures were in compliance with the European Communities Council Directive of 24 November 1986 (86/609/EEC). Efforts were made to minimize animal suffering and to reduce the number of animals used.

Experimental design

The model of schizophrenia was induced in methionine and methionine + oxytocin group through the daily subcutaneous administration of methionine (Sigma, USA) for 2 weeks ( $5.2 \mathrm{mmol} / \mathrm{kg}$ body weight (bw)).

After that, oxytocin was intraperitoneally injected in the methionine + oxytocin group in a dose of 10 $\mathrm{mg} / \mathrm{kg}$ bw for 9 consecutive days. The control group received $0.9 \%$ saline throughout the study. All the drug solutions were freshly prepared before use and dissolved in saline $(0.9 \% \mathrm{NaCl})$ a few minutes before the injection.

The oxytocin treatment began 7 days before the behavioural testing. Memory functions were tested through Y-maze, while anxiety was evaluated by elevated plus maze, both performed during the last 2 days of treatment ( $8^{\text {th }}$ and $9^{\text {th }}$ day, respectively).

In the testing days, oxytocin was given 15 min before performing the behavioural tests.

The aforementioned dosages, the duration of treatment and time of administration before testing were selected using our pilot studies and previously published reports regarding animal models of schizophrenia [12, 47, 48] and oxytocin half-life [41, 44].

\section{Behavioural tasks}

Y-maze task. Short-term memory was assessed by spontaneous alternation behaviour in the Y-maze task. The Y-maze used in the present study consisted of three arms (35 cm long, $25 \mathrm{~cm}$ high and $10 \mathrm{~cm}$ wide) and an equilateral triangular central area. The rat was placed at the end of one arm and allowed to move freely through the maze for $8 \mathrm{~min}$. An arm entry was counted when the hind paws of the rat were completely within the arm. Also, the maze was cleaned with alcohol-free disinfectant wipes between each trial. Spontaneous alternation behaviour was defined as the entry into all three arms on consecutive choices. The number of maximum spontaneous alternation behaviours was calculated as the total number of arms entered minus 2 and the percentage of spontaneous alternation was calculated as: (actual alternations/maximum alternations) $\times 100$. Spontaneous alternation behaviour is considered to reflect the spatial working memory, which is a form of short-term memory [50].

Elevated plus maze. The elevated plus maze (Coulbourn Instruments) consists of four arms, $49 \mathrm{~cm}$ long and $10 \mathrm{~cm}$ wide, elevated $50 \mathrm{~cm}$ off the ground. Two arms were enclosed by walls $30 \mathrm{~cm}$ high and the other two arms were exposed. Rats were placed at the juncture of the open and closed arms and the amount of time spent on the open arms was recorded during a 5-min test. Time spent on the open arms is considered to be an index of anxiety [51].

Tissue collection. After behavioural tests, all rats were anesthetized, rapidly decapitated and whole brains were removed. The temporal lobes were collected. Each of the temporal tissue samples was weighed and homogenized with a Potter Homogenizer coupled with Cole Parmer Servodyne Mixer in bidistiled water ( $1 \mathrm{~g}$ tissue $/ 10 \mathrm{~mL}$ bidistiled water). Samples were centrifuged $15 \mathrm{~min}$ at $3000 \mathrm{rpm}$. Following centrifugation, the supernatant was separated and pipetted into tubes [52]. 
Biochemical evaluations

Determination of superoxide dismutase. Superoxide dismutase activity was measured by the percentage of reaction inhibition rate of enzyme with WST-1 substrate (a water soluble tetrazolium dye) and xanthine oxidase using a SOD Assay Kit (Fluka, USA) according to the manufacturer's instructions. Each endpoint assay was monitored by absorbance at $450 \mathrm{~nm}$ (the absorbance wavelength for the coloured product of WST-1 reaction with superoxide) after $20 \mathrm{~min}$ of reaction time at $37^{\circ} \mathrm{C}$. The percentual inhibition was presented as SOD activity units.

Determination of glutathione peroxidase. Glutathione peroxidase activity was measured using the GPX cellular activity assay kit CGP-1 (Sigma Chemicals, USA). This kit uses an indirect method, based on the oxidation of glutathione (GSH) to oxidized glutathione (GSSG) catalysed by GPX, which is then coupled with recycling GSSG back to GSH utilizing glutathione reductase (GR) and NADPH. The decrease in NADPH at $340 \mathrm{~nm}$ during oxidation of NADPH to NADP is indicating the GPX activity. Determination of malondialdehyde. Malondialdehyde (MDA) levels were determined by thiobarbituric acid reactive substances (TBARs) assay. $200 \mu \mathrm{L}$ of supernatant was added and briefly mixed with $1 \mathrm{~mL}$ of trichloroacetic acid at $50 \%, 0.9 \mathrm{~mL}$ of Tris- $\mathrm{HCl}$ (pH 7.4) and $1 \mathrm{~mL}$ of thiobarbituric acid $0.73 \%$. After vortex mixing, samples were maintained at $100^{\circ} \mathrm{C}$ for $20 \mathrm{~min}$. Afterwards, samples were centrifuged at $3000 \mathrm{rpm}$ for $10 \mathrm{~min}$ and supernatant read at $532 \mathrm{~nm}$. The signal was read against an MDA standard curve and the results were expressed as $\mathrm{nmol} / \mathrm{mg}$ protein [53].

Data analysis

The animals' behaviour in Y maze (as expressed through spontaneous alternation and number of arm entries) and elevated plus maze (as expressed through the time in the open-arms) and the levels of oxidative stress markers (SOD, GPX and MDA) were statistically analysed by using one-way analysis of variance (ANOVA). All results are expressed as mean \pm SEM. Post hoc analysis was performed using Tukey's honestly significant difference test in order to compare groups. $p<0.05$ was considered statistically significant.

\section{Results and Discussion}

Regarding the results in the $\mathrm{Y}$ maze behavioural test, as a marker of immediate spatial memory (a hippocampal dependent test [54]) we could observe a significant decrease in the spontaneous alternation percentage in both methionine $(p=0.03)$ and methionine + oxytocin treated rats $(\mathrm{p}=0.2)$, as compared to the controls (Figure 1).
Also, when we applied the post hoc analysis we could observe a significant increase of the spontaneous alternation in the oxytocin treated rats, as compared to those receiving only methionine $(p=0.04)$ (Figure 1).

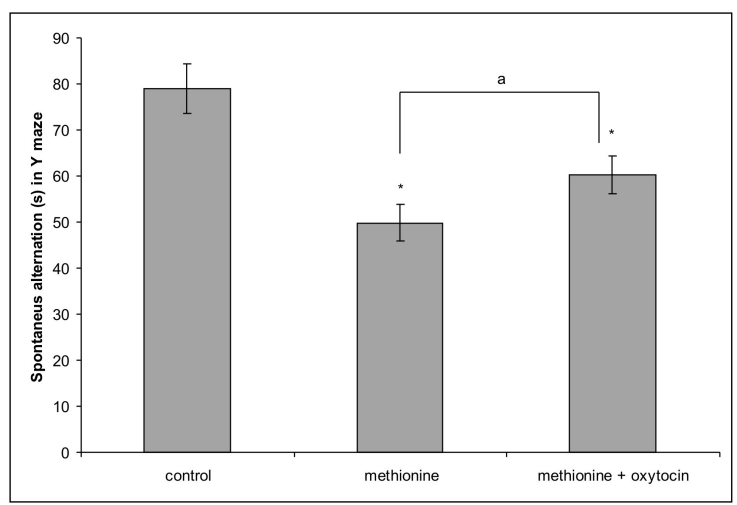

Figure 1.

The effects of methionine-induced rat model of schizophrenia and oxytocin administration on the spontaneous alternation percentage in the Y-maze task. ${ }^{*} \mathrm{p}<0.05$ vs. control; post-hoc analysis - a (methionine vs. methionine + oxytocin): $\mathrm{p}=0.04$.

Moreover, the number of arm entries was not significantly modified between the research groups $(\mathrm{p}>0.05)$, suggesting that the aforementioned spontaneous alternation result could be attributed to some immediate spatial memory deficits (Figure 2).

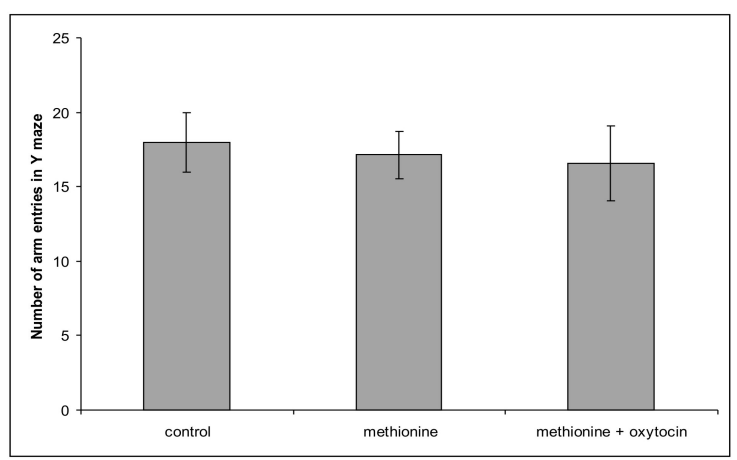

Figure 2.

The effects of methionine-induced rat model of schizophrenia and oxytocin administration on the number of arm entries in the Y-maze task.

In addition, our data showed that methionine resulted in a significant decrease of the time spent by the rats with this model of schizophrenia in the open arms of the elevated plus maze, in both methionine $(\mathrm{p}=0.02)$ and methionine + oxytocin $(\mathrm{p}=0.03)$ groups, suggesting some anxiogenic effects [55] (Figure 3).

Still, the intraperitoneal administration of oxytocin improved the time spent by the rats in the open arms of the elevated plus maze $(p=0.03)$, as 
compared to those which received methionine only, as showed by the post-hoc analysis (Figure 3 ).

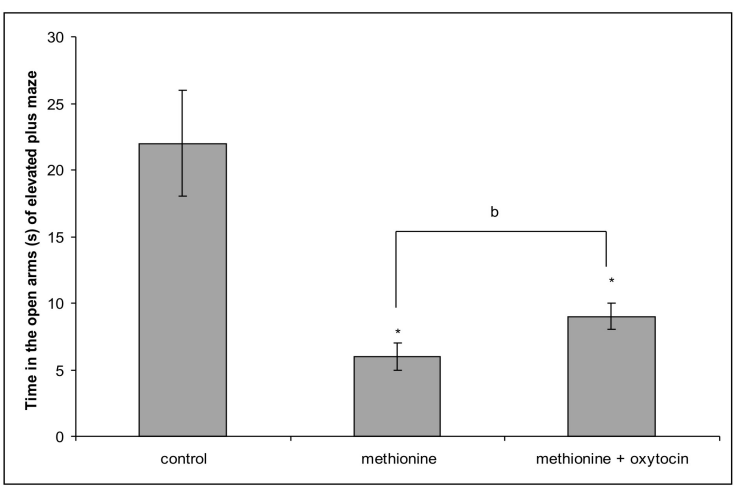

Figure 3.

The effects of methionine-induced rat model of schizophrenia and oxytocin administration on the time spent in the open-arms of the elevated plus maze. ${ }^{*} \mathrm{p}<0.05 v s$. control; post-hoc analysis - b (methionine $v s$. methionine + oxytocin): $\mathrm{p}=0.03$.

Regarding the oxidative stress parameters we focused on determining 3 main biomarkers of the oxidative stress status: two antioxidant enzymes (SOD and GPX) and the lipid peroxidation biomarker (MDA) from the temporal lobe, the most sensitive brain area to the effects of the oxidative stress metabolism [49].

Thus, when it comes to the first antioxidant enzyme in the way of the free radicals, SOD [56], we could not determine any significant modification between our 3 research groups on its inhibition rate percentage $(p>0.05)$, as it can be seen in the Figure 4 .

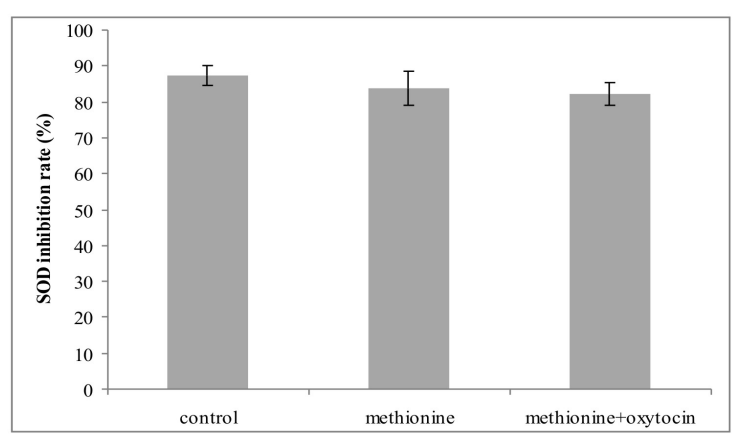

Figure 4.

The effects of methionine-induced rat model of schizophrenia and oxytocin administration on the superoxide dismutase (SOD) inhibition rate (\%) in the temporal lobe.

However, in the case of the second antioxidant enzyme we determined, GPX, we could observe a significant increase in its enzymatic activity in the case of oxytocin administration, as compared to the controls $(p=0.03)$ (Figure 5).
In addition, post-hoc analysis demonstrated a significant difference also between oxytocin treated rats and those receiving only methionine $(\mathrm{p}=0.04)$ (Figure 5).

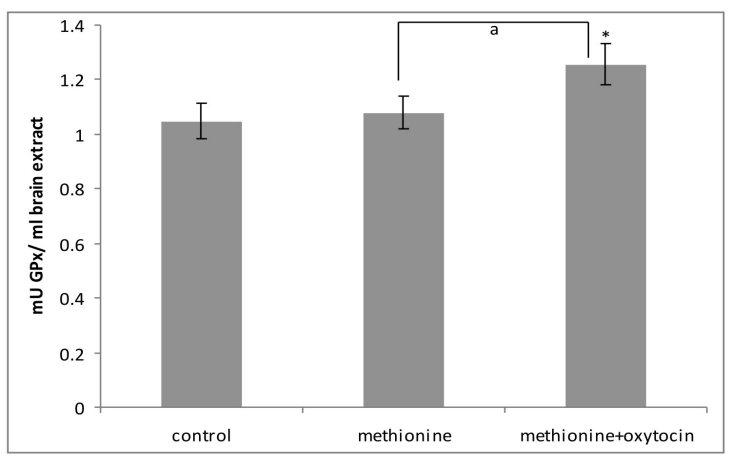

Figure 5.

The effects of methionine-induced rat model of schizophrenia and oxytocin administration on the glutathione peroxidase (GPX) specific activity in the

temporal lobe. $* p=0.03$ vs. control; post-hoc analysis - a (methionine $v s$. methionine + oxytocin):

$$
\mathrm{p}=0.04 \text {. }
$$

Regarding the MDA levels, our data demonstrated only a significant increase in MDA activity in the oxytocin group, when compared to the controls $(\mathrm{p}=$ 0.03) (Figure 6).

Even more important is the fact that oxytocin did significantly decrease the MDA levels from the temporal lobe, when compared to the methionine group ( $p=0.04)$, as suggested by the post-hoc analysis (Figure 6).

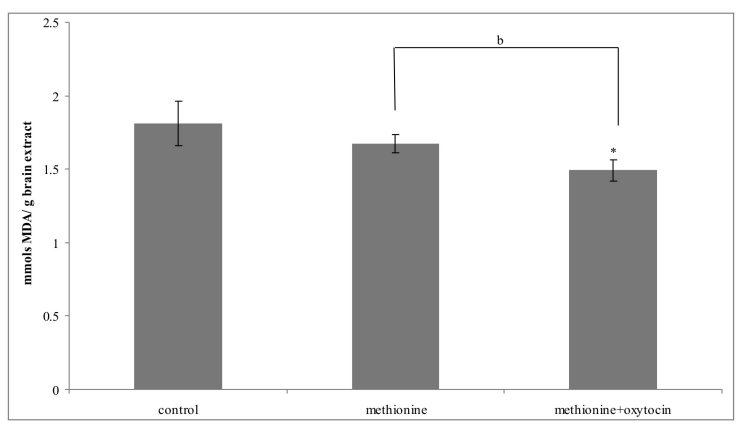

Figure 6.

The effects of methionine-induced rat model of schizophrenia and oxytocin administration on the malondialdehyde (MDA) concentration in the temporal lobe. $* \mathrm{p}=0.03 \mathrm{vs}$. control; post-hoc analysis - $\mathrm{b}$ (methionine $v s$. methionine + oxytocin): $\mathrm{p}=0.04$.

In this paper we demonstrated some ameliorative effects of intraperitoneally oxytocin administration for 9 days on the immediate spatial memory and anxiety-induced deficits generated in the $\mathrm{Y}$ maze and elevated plus maze by a methionine-induced rat model of schizophrenia. 
Even more, oxytocin administration exerted some antioxidant effects in this model, as demonstrated by increased specific activity of GPX and reduced levels of MDA from the temporal lobe in the methionine + oxytocin group, as compared to the methionine administered rats. However, no significant modifications in SOD specific activity were found.

As mentioned before, lately there is a lot of interest in understanding the relevance of oxytocin administration in schizophrenia. In this way, one of the first studies in this area was performed by the Guastella group in Sydney, Australia, which demonstrated that just one single dose of intranasal administrated oxytocin (24 IU) could increase higher-order social cognition in schizophrenia, as judged by specific tests for social cognition tasks and general neurocognition [26].

However, in august 2017, in a report which studied the possible influence of separately intranasal administration oxytocin and galantamine on the negative symptoms exhibited in the schizophrenic pathology and the associated cognitive impairments in 17 patients with schizophrenia, the Buchanan group clearly stated that there is absolutely no effect of oxytocin in these two directions [27].

Also, additional research groups showed for example that oxytocin administration (e.g. by using the intranasal route) exerts no significant effects on other schizophrenic-related behaviours, such as "jumping to conclusions"-like manifestations, in a study performed on 43 medicated male schizophrenics and where the number of fewer draws to decisions was counted in relation to the aforementioned behaviours [31].

Still, most of the studies in this area of research are showing mixed effects, in which some features of the schizophrenic pathology seems to be ameliorated by oxytocin administration, while others do not suffer any significant modifications. For example, Wooley et al. [32] showed that oxytocin administration does not influence the feelings related to trustworthiness (as judged by specific video-analysis in 33 patients with schizophrenia), but instead it increases the facial expressivity in these patients [32]. In the same way, other studies [37] showed that intranasal oxytocin administration increases the scores in specific scales such as Mayer-Salovey-Caruso Emotional Intelligence Test, but does not influence implicit priming and the so-called "theory of mind" abilities in 31 tested patients with schizophrenia [37].

Still, one review paper [29] and 3 meta-analysis $[28,30,35]$ published in the last year on this topic showed rather negative results, with only one of them stating some positive effects on general socialcognition and neuro-cognition [28] and the other two meta-analysis stating clearly that "intranasal oxytocin is not an effective therapy for schizophrenia" [35] or that it exerts no significant effects on expression of emotions in most of the clinical populations also including other disorders besides schizophrenia [30].

All these contradictory results could be mainly explained by the incompletely understood complexity of the oxytocinergic system in the body, the variety of behaviours, methods and scales used in these studies, the different symptoms assessed, the different species used sometimes or the route used for the oxytocin administration (e.g. peripheral $v s$. intranasal one), as well as the different ways to administrate oxytocin intranasal, if this way of administration is used [57].

There are also evidences suggesting that the dysfunctions in the oxytocin system could be also related to the metabolic deficiencies which are encountered in more than $30 \%$ of the patients with schizophrenia [33].

Also, mechanistically speaking, there are reports stating a possible correlation between the oxytocin receptor methylation and cognitive functions in patients with schizophrenia, psychotic or schizoaffective disorders [34], while other demonstrated a decreased gene expression for the oxytocin receptor gene and its binding sites in several specific brain regions of the schizophrenic patients, such as the temporal cortex or the vermis [39].

Another issue regarding the oxytocin administration is referring to its very low half-life, as there are studies demonstrating for example that 3 weeks of chronic intranasal administration (twice a day in a dose of 20 IU) did not result in any modifications of plasma oxytocin concentrations in patients with schizophrenia or any significant improvements of some of their negative symptoms [41]. Even more, in a study which involved 4 months of daily oxytocin administration (in a dose of $40 \mathrm{IU}$ ) in patients with schizophrenia, there were still no significant modifications detected in the plasma levels of oxytocin, as compared to placebo group [43].

The relevance of oxytocin in the social context was also studied in the zebrafish, considering the importance of such behaviour in this species, [58-60], with a study clearly demonstrating that oxytocin is rescuing the social deficits induced by MK-801, which is a NMDA receptor antagonist [38]. Even more, the same group showed that the administration of carbetocin (an oxytocin receptor agonist) is also rescuing both the social and aggressive deficits induced by MK801 [38].

Regarding the results we obtained in the present study, we reported here a significant decrease of immediate working memory in Y maze (e.g. affected spontaneous alternation), which was attenuated by the oxytocin administration, while in the elevated plus maze oxytocin also rescued some anxiety-like deficits related to a decreased time spent by the rats in the open arms of the maze. 
Thus, as we mentioned above, when it comes to the memory deficits in schizophrenia, this could be a quite common manifestation, as general cognitive problems are reported in around three quarters of patients with schizophrenia (with deficits ranging from decreased memory and attention to affected executive functions and intelligence) [13]. However, there are still controversies in this area of research also, with some groups demonstrating that methionine administration $(100 \mathrm{mg} / \mathrm{kg}$ bw) could increase brainderived neurotrophic factor (BDNF) DNA methylation and improve in the same time the memory processes in a kaininc-acid induced model of epilepsy in rats [61].

Still, in the paper of Wang et al., describing the methionine-induced rat model of schizophrenia [12], the authors reported less exploration of the novel object in the specific behavioural task, combined with deficits in the inhibitory avoidance acquisition, while it is also known that methionine-induced hyperhomocysteinemia could represent an important mechanistically aspect in disorders such as schizophrenia, but also in Alzheimer's disease, depression and bipolar disorder [62].

As mentioned, we also demonstrated here significant deficits in the immediate spatial memory, as studied in the Y maze task (e.g. a significant decrease of spontaneous alternation in the methionine group, as compared to the control rats).

Also, according to our best of knowledge, there is no other study in the literature on the effects exerted by this methionine-induced rat model of schizophrenia on memory, except for our previous preliminary reports on this matter [47, 48].

Regarding the anxiety manifestations in schizophrenia and in particular in our methionine-rat model of schizophrenia, things are also uncertain, with the previous report of Wang et al. describing no effects on anxiety, as studied in open field test [12]. However, we did found in the present report some increased anxiety manifestation in this methioninerat model of schizophrenia, as showed for example by the reduced time spent in the open arms of the elevated plus maze task. We should also mention that most of the recent studies in this area are acknowledging that almost $65 \%$ of the patients with schizophrenia are exhibiting anxiety-related manifestations [63, 64].

As mentioned, the Wang study [12] is presenting some phenotypic cognitive deficits, especially at the level of novel object recognition test, where some deficits in discriminating from new and old object were observed, while in the inhibitory avoidance assay, there was a significant decrease for the latency to enter in the dark room, 48 hours after training. Also, the positive symptoms of this methionine-rat model of schizophrenia were replicated through the hyperactive locomotor behaviour and the stereotypic manifestations, while the negative one were represented by decreased sociability in the 3 chambered test. Also, no effects on pain-related behaviour were reported $[13,65]$.

In addition, according to our best of knowledge, this is also the first time in the literature when the oxidative stress status is assessed in this methioninerat model of schizophrenia, except from our previous short communications in this matter [69].

Thus, when it comes to the effects of methionine on the oxidative stress status, most of the results are also controversial, with reports about both its prooxidant $[66,68]$ and antioxidant effects $[67,70,71]$.

In this way, only a $2 \%$ supplemented methionine-diet in rabbits is resulting in increased oxidative stress status, as judged by the modifications of some specific parameters such as MDA, homocysteine or diene conjugate from the serum, heart or aorta [66]. Also, pro-oxidant effects of methionine were demonstrated as a result an $80 \%$ dietary restriction of methionine, which generated a decreased oxidative stress status, as demonstrated by determining some main oxidative stress parameters (e.g. glutathione concentration, GPX, 8-hydroxydeoxyguanosine or 8-isoprostane) from the brain, blood, liver and kidney [68]. However, no significant modifications of SOD specific activity were found in this study [68], probably considering that this is the first enzyme in the way of the reactive oxygen species, suffering compensatory modifications [56]. Even more, it is believed that this methionine dietary-restriction could delay the process of aging [68], considering the oxidative stress theory of aging [72, 73].

On the opposite, there are authors clearly stating the antioxidant actions for methionine, which is described as a "scavenger" by the Cambell group [67], with some indirect effects caused by NADPH altered activity. Even more, Luo et al. considered that methionine could act as a "molecular bodyguard", by protecting the tryptophan residue [70]. In addition, the results of the aforementioned Cambell study [67] were also confirmed by Eriksson et al., which proved that methionine could protect from the increased oxidative stress status by offering an alternative to the classical NADPH reducing way [71].

However, our results showed there is no significant modification of SOD and GPX activities, as well as for MDA concentrations from the temporal lobe.

As also mentioned before, oxytocin administration is known for generating controversial effects on the oxidative stress metabolism, with studies demonstrating antioxidant actions on the renal level [44, 74], as well as protective effects against nitric oxide (e.g. nitrosative stress [77]) and cytokine production [75] or attenuating NADPH-dependent superoxide activity and interleukin 6 secretion [76], while on the other side reports clearly stating its prooxidant actions [46]. 
Still, when it comes to the oxytocin effects on the oxidative stress status, we demonstrated in the present report some antioxidant effects of $10 \mathrm{mg} / \mathrm{kg}$ bw i.p. oxytocin, administrated for 9 consecutive days in a methionine-induced rat model of schizophrenia, considering that GPX specific activity from the temporal lobe was significantly increased and the MDA concentration was decreased in the methionine + oxytocin group, when compared to methionine rats. However, no significant modifications were found for SOD specific activity, probably as a result of some compensatory mechanisms.

We should also mention, as a limitation of our study, that we administered oxytocin intraperitoneally. However, our new approach of administrating oxytocin and the general efforts to understand the peripheral oxytocinergic effects [41] could be justified by the very recent debate about a better understanding of oxytocin-related mechanisms, as well as the fact that central and peripheral oxytocin concentrations could be actually related to oxytocin administration [79]. Also, an important aspect in this matter is represented by the fact that several other authors previously demonstrated effects exerted by peripheral oxytocin administration on social behaviour, anxiety and the cognitive functions [80-84].

\section{Conclusions}

The present paper demonstrates some ameliorative effects of oxytocin administration on the immediate spatial memory (increased spontaneous alternation in $\mathrm{Y}$ maze) and anxiety-induced deficits (oxytocin increased the time spent in the open arms of the elevated plus maze) generated by the methionineinduced rat model of schizophrenia. Even more, oxytocin administration exerted some antioxidant effects in this model, as demonstrated by increased specific activity of GPX and reduced levels of MDA from the temporal lobe in the methionine + oxytocin group, as compared to the methionine group of rats. However, no significant modifications in SOD specific activity were found. This could have further relevance for the reason behind the possible administration of oxytocin in the schizophrenia pathophysiology.

\section{Acknowledgement}

The authors (except Sabina Cojocaru, Harquin Foyet and Veronica Bild - which have no other potential conflict to disclose) were supported by a research grant PN II PN-II-RUTE-2014-4-1886 called "A complex study regarding the relevance of oxytocin administration in some animal models of neuropsychiatric disorders".

\section{References}

1. Balmus IM, Ciobica A, Negura A, Negura L, Anton E, Basic aspects in selecting a suitable transgenic rodent model for Alzheimer's disease. Psychiatr Danub., 2015; 27(4): 338-345.

2. Ciobica A, Olteanu Z, Padurariu M, Hritcu L, The effects of pergolide on memory and oxidative stress in a rat model of Parkinson's disease. $J$ Physiol Biochem., 2012; 68(1): 59-69.

3. Bild W, Ciobica A, Angiotensin-(1-7) central administration induces anxiolytic-like effects in elevated plus maze and decreased oxidative stress in the amygdala. $J$ Affect Disord., 2013; 145(2): 165-171.

4. Ciobica A, Bild V, Hritcu L, Padurariu M, Bild W, Effects of angiotensin II receptor antagonists on anxiety and some oxidative stress markers in rat. CEJMed., 2011; 6(3): 331-340.

5. Shepherd M, Two faces of Emil Kraepelin. $\mathrm{Br} J$ Psychiatry, 1995; 167(2): 174-183.

6. Lefter R, Cojocaru D, Ciobica A, Paulet IM, Serban IL, Anton E, Aspects of animal models for the major neuropsychiatric disorders. Arch Bio Sci Belgr., 2014; 66(3): 1105-1115.

7. Marcotte ER, Pearson DM, Srivastava LK, Animal models of schizophrenia: a critical review. $J$ Psychiatry Neurosci., 2001; 26(5): 395-410.

8. Mavroudis IA, Petrides F, Manani M, Chatzinikolaou F, Ciobică A, Pădurariu M, Kazis D, Njau SN, Costa VG, Baloyannis SJ, Purkinje cells pathology in schizophrenia. A morphometric approach. Rom J Morphol Embryol., 2017; 58(2): 419-424.

9. Jones C, Watson D, Fone K, Animal models of schizophrenia. Br J Pharmacol., 2011; 164(4): 1162-1194.

10. Wilson C, Terry AVJr, Neurodevelopmental animal models of schizophrenia: role in novel drug discovery and development. Clin Schizophr Relat Psychoses, 2010; 4(2): 124-137.

11. Crawley JN, Designing mouse behavioral tasks relevant to autistic-like behaviors. Ment Retard Dev Disabil Res Rev., 2004; 10(4): 248-258.

12. Wang L, Alachkar A, Sanathara N, Belluzzi JD, Wang Z, Civelli O, A Methionine-Induced Animal Model of Schizophrenia: Face and Predictive Validity. IJNP, 2015; 18(12): pyv054.

13. O'Carroll $\mathrm{R}$, Cognitive impairment in schizophrenia. BJPsych Advances, 2000; 6(3): 161-168.

14. Padurariu M, Ciobica A, Dobrin I, Stefanescu C, Evaluation of antioxidant enzymes activities and lipid peroxidation in schizophrenic patients treated with typical and atypical antipsychotics. Neurosci Lett., 2010; 479(3): 317-320.

15. Dehelean L, Andor M, Romoşan AM, Manea MM, Romoşan RŞ, Papavă I, Bredicean AC, Buda VO, Tomescu MC, Pharmacological and disorder associated cardiovascular changes in patients with psychosis. A comparison between olanzapine and risperidone. Farmacia, 2018; 66(1): 129-134.

16. Dobrin R, Dobrin I, Stefanescu C, Ciobica A, Serban IL, Anton E, A Direct Correlation Between The Scores Of PANSS/AIMS Scales And Some 
FARMACIA, 2018, Vol. 66, 3

Oxidative Stress Markers In Treated Schizophrenic Patients. Arch Bio Sci Belgr., 2014; 66(4): 1559-1565.

17. Raffa M, Mechri A, Othman LB, Fendri C, Gaha L, Kerkeni A, Decreased glutathione levels and antioxidant enzyme activities in untreated and treated schizophrenic patients. Prog Neuropsychopharmacol Biol Psychiatry, 2009; 33: 1178-1183.

18. Dadheech G, Mishra S, Gautam S, Sharma P, Evaluation of antioxidant deficit in schizophrenia. Indian J Psychiatry, 2008; 50: 16-20.

19. Zhang XY, Zhou DF, Su JM, Zhang PY, The effect of extract of Ginkgo biloba added to haloperidol on superoxide dismutase in patients with chronic schizophrenia. J Clin Psychopharmacol., 2001; 21: 85-88.

20. Zhang XY, Zhou DF, Zhang PY, Wu GY, Su JM, Cao LY, A double-blind, placebo-controlled trial of extract of Ginkgo biloba added to haloperidol in treatment-resistant patients with schizophrenia. $J$ Clin Psychiatry, 2001; 62: 878-883.

21. Padurariu M, Ciobica A, Balmus IM, Dobrin R, Lefter R, Stefanescu C, Timofte D, Current Aspects Regarding the Biological, Psychological and Social Implications of Oxytocin in the Affective Disorders. Rom J Psychopharmacol., 2014; 14(3): 180-186.

22. Guastella AJ, Hickie IB, Oxytocin Treatment, Circuitry, and Autism: A Critical Review of the Literature Placing Oxytocin Into the Autism Context. Biol Psychiatry, 2016; 79(3): 234-242.

23. Padurariu M, Antioch I, Balmus I, Ciobica A, Heba SEL, Mervat MK, Describing some behavioural animal models of anxiety and their mechanistics with special reference to oxidative stress and oxytocin relevance. Int $J$ Vet Sci Med., 2017; 5(2): 98-104.

24. Ciobica A, Balmus IM, Padurariu M, Is oxytocin relevant for the affective disorders?. Acta Endocrinol., 2016; 12(1): 65-71.

25. Padurariu M, Prepelita R, Ciobica A, Dobrin R, Timofte D, Stefanescu C, Chirita R, The concept of suicide: neurophysiological/genetic theories and possible oxytocin relevance. Neurophysiol., 2016; 48(4): 312-321.

26. Guastella AJ, Ward PB, Hickie IB, Shahrestani S, Hodge MA, Scott EM, Langdon R, A single dose of oxytocin nasal spray improves higher-order social cognition in schizophrenia. Schizophr Res., 2015; 168(3): 628-633.

27. Buchanan RW, Kelly DL, Weiner E, Gold JM, Strauss GP, Koola MM, McMahon RP, Carpenter WT, A Randomized Clinical Trial of Oxytocin or Galantamine for the Treatment of Negative Symptoms and Cognitive Impairments in People With Schizophrenia. J Clin Psychopharmacol., 2017; 37(4): 394-400.

28. Bürkner PC, Williams DR, Simmons TC, Woolley JD, Intranasal Oxytocin May Improve High-Level Social Cognition in Schizophrenia, But Not Social Cognition or Neurocognition in General: A Multilevel Bayesian Meta-analysis. Schizophr Bull., 2017; 43(6): 1291-1303.

29. Bradley ER, Woolley JD, Oxytocin effects in schizophrenia: Reconciling mixed findings and moving forward. Neurosci Biobehav Rev., 2017; 12(80): 36-56.

30. Leppanen $\mathrm{J}, \mathrm{Ng} \mathrm{KW}$, Tchanturia $\mathrm{K}$, Treasure J, Meta-analysis of the effects of intranasal oxytocin on interpretation and expression of emotions. Neurosci Biobehav Rev., 2017; 78: 125-144.

31. Caravaggio F, Gerretsen P, Mar W, Chung JK, Plitman E, Nakajima S, Kim J, Iwata Y, Patel R, Chakravarty MM, Remington G, Graff-Guerrero A, Menon M, Intranasal oxytocin does not modulate jumping to conclusions in schizophrenia: Potential interactions with caudate volume and baseline social functioning. Psychoneuroendocrinol., 2017; 81: 80-87.

32. Woolley JD, Chuang B, Fussell C, Scherer S, Biagianti B, Fulford D, Mathalon DH, Vinogradov $\mathrm{S}$, Intranasal oxytocin increases facial expressivity, but not ratings of trustworthiness, in patients with schizophrenia and healthy controls. Psychol Med., 2017; 47(7): 1311-1322.

33. Quintana DS, Dieset I, Elvsåshagen T, Westlye LT, Andreassen OA, Oxytocin system dysfunction as a common mechanism underlying metabolic syndrome and psychiatric symptoms in schizophrenia and bipolar disorders. Front Neuroendocrinol., 2017; 45: $1-10$.

34. Grove TB, Burghardt KJ, Kraal AZ, Dougherty RJ, Taylor SF, Ellingrod VL, Oxytocin Receptor (OXTR) Methylation and Cognition in Psychotic Disorders. Mol Neuropsychiatry., 2016; 2(3): 151-160.

35. Williams DR, Bürkner PC, Effects of intranasal oxytocin on symptoms of schizophrenia: A multivariate Bayesian meta-analysis. Psychoneuroendocrinol., 2017; 75: 141-151.

36. Bhome R, Howard R, Oxytocin, trust and very lateonset schizophrenia-like psychosis. Int $J$ Geriatr Psychiatry., 2016; 31(12): 1373-1374.

37. Brambilla M, Cotelli M, Manenti R, Dagani J, Sisti D, Rocchi M, Balestrieri M, Pini S, Raimondi S, Saviotti FM, Scocco P, de Girolamo G, Oxytocin to modulate emotional processing in schizophrenia: A randomized, double-blind, cross-over clinical trial. Eur Neuropsychopharmacol., 2016; 26(10): 16191628.

38. Zimmermann FF, Gaspary KV, Siebel AM, Bonan $\mathrm{CD}$, Oxytocin reversed MK-801-induced social interaction and aggression deficits in zebrafish. Behav Brain Res., 2016; 311: 368-374.

39. Uhrig S, Hirth N, Broccoli L, von Wilmsdorff M, Bauer M, Sommer C, Zink M, Steiner J, Frodl T, Malchow B, Falkai P, Spanagel R, Hansson AC, Schmitt A, Reduced oxytocin receptor gene expression and binding sites in different brain regions in schizophrenia: A post-mortem study. Schizophr Res., 2016; 177(1-3): 59-66.

40. Shilling PD, Feifel D, Potential of Oxytocin in the Treatment of Schizophrenia. CNS Drugs. 2016; 30(3): 193-208.

41. Lee MR, Wehring HJ, McMahon RP, Liu F, Linthicum J, Verbalis JG, Buchanan RW, Strauss GP, Rubin LH, Kelly DL, Relationship of plasma oxytocin levels to baseline symptoms and symptom changes during three weeks of daily oxytocin administration in people with schizophrenia. Schizophr Res., 2016; 172(1-3): 165-168. 
FARMACIA, 2018, Vol. 66, 3

42. Bukovskaya O, Shmukler A, Oxytocin and Social Cognitions in Schizophrenia: A Systematic Review. Psychiatr Q., 2016; 87(3): 521-543.

43. Busnelli M, Dagani J, de Girolamo G, Balestrieri M, Pini S, Saviotti FM, Scocco P, Sisti D, Rocchi M, Chini B, Unaltered Oxytocin and Vasopressin Plasma Levels in Patients with Schizophrenia After 4 Months of Daily Treatment with Intranasal Oxytocin. J Neuroendocrinol., 2016; 28(4).

44. Biyikli NK, Tuğtepe H, Sener G, Velioğlu-Oğünç A, Cetinel S, Midillioğlu S, Gedik N, Yeğen BC, Oxytocin alleviates oxidative renal injury in pyelonephritic rats via a neutrophil-dependent mechanism. Peptides, 2006; 27(9): 2249-2257.

45. Honceriu C, Ciobica A, Stoica B, Chirazi M, Padurariu M, Oxytocin Antioxidant Effects on Wistar Rats. Rev Chim. (Bucharest), 2016; 67(11): 2246-2249.

46. Iqbal Z, Rahman ZU, Muhammad F, Khaliq T, Anwar H, Awais MM, Sadaf S, Oxytocin induced oxidative stress in lactating Bubalis bubalis (Nili Ravi). BMC Vet Res., 2013; 27(9): 169.

47. Ciobica A, Lefter R, Paulet IM, Antioch I, Dobrin $\mathrm{R}$, Short term oxytocin administration is reducing memory deficits and anxiety manifestations in a methionine-rat model of schizophrenia, $23^{\text {rd }}$ International "Stress and Behavior" Neuroscience and Biopsychiatry Conference May 16-19, St. Petersburg, Russia; 2016; pg. 31.

48. Padurariu M, Lefter R, Ciobica A, Paulet IM, Dobrin $\mathrm{R}$, Intraperitoneal oxytocin administration for 9 consecutive days is reducing memory deficits and anxiety in a methionine rat model of schizophrenia. Eur Neuropsychopharmacol., 2016; 26(2): 289-290.

49. Karelson E, Bogdanovic N, Garlind A, Winblad B, Zilmer K, Kullisaar T, Vihalemm T, Kairane C, Zilmer $\mathrm{M}$, The cerebrocortical areas in normal brain aging and in Alzheimer's disease: noticeable differences in the lipid peroxidation level and in antioxidant defense. Neurochem Res., 2001; 26(4): 353-361.

50. Gurzu C, Artenie V, Hritcu L, Ciobica A, Prenatal testosterone improves the spatial learning and memory by protein synthesis in different lobes of the brain in the male and female rat. Cent Eur $J$ Biol., 2008; 3(1): 39-47.

51. Ciobica A, Hritcu L, Nastasa V, Padurariu M, Bild $\mathrm{W}$, Inhibition of central angiotensin converting enzyme exerts anxiolytic effects by decreasing brain oxidative stress. J Med Biochem., 2011; 30(2): 109-114.

52. Hritcu L, Ciobica A, Gorgan L, Nicotine-induced memory impairment by increasing brain oxidative stress. Cent Eur J Biol., 2009; 4(3): 335-342.

53. Ciobica A, Padurariu M, Hritcu L, The effects of short-term nicotine administration on behavioral and oxidative stress deficiencies induced by a rat model of Parkinson's disease. Psychiatr Danub., 2012; 24(2): 194-205.

54. Lazaroni TL, Raslan AC, Fontes WR, de Oliveira ML, Bader M, Alenina N, Moraes MF, Dos Santos RA, Pereira GS, Angiotensin-(1-7)/Mas axis integrity is required for the expression of object recognition memory. Neurobiol Learn Mem., 2012; 97(1): 113-123.
55. Ababei DC, Lefter R, Ciobica A, Antioh I, Barbu R, Arcan O, Beșchea Chiriac S, Zbârcea C, Bild W, Bild V, Effects Of Renin-Angiotensin System Blockade On Anxiety And Memory In Mice. Farmacia, 2017; 65(3): 381-389.

56. Haulica I, Boişteanu D, Bild W, Free radicals between health and disease. Rom J Physiol., 2000; 37(1-4): 15-22.

57. Guastella AJ, Hickie IB, McGuinness MM, Otis M, Woods EA, Disinger HM, Chan HK, Chen TF, Recommendations for the standardisation of oxytocin nasal administration and guidelines for its reporting in human research. Psychoneuroendocrinol., 2013; 38(5): 612-625.

58. Plavan G, Ciobica A, Nicoara M, Timofte D, The Biomaterial Relevance of Oxytocin in Some Zebrafish Studies. Key Engineering Materials, 2015; 660: 289-293.

59. Balmus IM, Strungaru SA, Plavan G, Ciobica A, Nicoara M, Direct exposure to oxytocin results in increased social behavior and mobility performances in a zebrafish animal model. $13^{\text {th }}$ World Congress of Biological Psychiatry; the World Federation of Societies of Biological Psychiatry (WFSBP) Copenhagen, 2017; poster number 024, pg. 58.

60. Strungaru SA, Balmus IM, Plavan G, Ciobica A, Nicoara M, Oxytocin water exposure significantly increases social behavior and locomotor activity in a zebrafish animal model. $5^{\text {th }}$ International Congress on Neurobiology, Psychopharmacology and Treatment Guidance, Chalikidiki, Greece, 2017; poster number P 61, pg. 147.

61. Parrish RR, Buckingham SC, Mascia KL, Johnson JJ, Matyjasik MM, Lockhart RM, Lubin FD, Methionine increases BDNF DNA methylation and improves memory in epilepsy. Ann Clin Transl Neurol., 2015; 2(4): 401-416.

62. de Rezende MM, d'Almeida V, Central and systemic responses to methionine-induced hyperhomocysteinemia in mice. PLoS One, 2014; 9(8): e105704.

63. Temmingh H, Stein DJ, Anxiety in Patients with Schizophrenia: Epidemiology and Management. CNS Drugs, 2015; 29(10): 819-832.

64. Braga RJ, Petrides G, Figueira I, Anxiety disorders in schizophrenia. Compr Psychiatry, 2004; 45(6): 460-468.

65. Antioch I, Ciobica A, Paulet M, Bild V, Lefter R, Timofte D, Pain manifestations in schizophrenia clinical and experimental aspects in human patients and animal models. Psychiatr Danub., 2015; 27(2): $142-152$

66. Yalçinkaya-Demirsöz S, Depboylu B, Dogru-Abbasoglu $\mathrm{S}$, Unlüçerçi $\mathrm{Y}$, Uysal M, Effects of high methionine diet on oxidative stress in serum, apo-B containing lipoproteins, heart, and aorta in rabbits. Ann Clin Lab Sci., 2009; 39(4): 386-391.

67. Campbell K, Vowinckel J, Keller MA, Ralser M, Methionine Metabolism Alters Oxidative Stress Resistance via the Pentose Phosphate Pathway. Antioxid Redox Signal, 2016; 24(10): 543-547.

68. Maddineni S, Nichenametla S, Sinha R, Wilson RP, Richie JPJr, Methionine restriction affects oxidative stress and glutathione-related redox 
pathways in the rat. Exp Biol Med (Maywood), 2013; 238(4): 392-399.

69. Balmus IM, Ciobica A, Lefter R, Cojocaru S, No clear effects of oxytocin on oxidative stress status in a rat epigenetic model of schizophrenia based on methionine administration. The Annual International Conference of the Romanian Society for Biochemistry \& Molecular Biology, Timisoara, 2017; poster number S3_P7. New Front Chem J., 2017; 26, (2).

70. Luo S, Levine RL, Methionine in proteins defends against oxidative stress. FASEB J., 2009; 23(2): 464-472.

71. Eriksson S, Prigge JR, Talago EA, Arnér ES, Schmidt EE, Dietary methionine can sustain cytosolic redox homeostasis in the mouse liver. Nat Commun., 2015; 20(6): 6479

72. Padurariu M, Ciobica A, Hritcu L, Stoica B, Bild W, Stefanescu C, Changes of some oxidative stress markers in the serum of patients with mild cognitive impairment and Alzheimer's disease. Neurosci Lett., 2010; 18; 469(1): 6-10.

73. Padurariu M, Ciobica A, Lefter R, Serban IL, Stefanescu C, Chirita R, The oxidative stress hypothesis in Alzheimer's disease. Psychiatr Danub., 2013; 25(4): 401-409.

74. Tuğtepe H, Sener G, Biyikli NK, Yüksel M, Cetinel $\mathrm{S}$, Gedik N, Yeğen BC, The protective effect of oxytocin on renal ischemia/reperfusion injury in rats. Regul Pept., 2007; 140(3): 101-108.

75. Oliveira-Pelegrin GR, Saia RS, Cárnio EC, Rocha MJ, Oxytocin affects nitric oxide and cytokine production by sepsis-sensitized macrophages. Neuroimmunomodulation, 2013; 20(2): 65-71.

76. Szeto A, Nation DA, Mendez AJ, DominguezBendala J, Brooks LG, Schneiderman N, McCabe PM, Oxytocin attenuates NADPH-dependent superoxide activity and IL-6 secretion in macrophages and vascular cells. Am J Physiol Endocrinol Metab., 2008; 295(6): E1495-1501.

77. Bild W, Ciobica A, Padurariu M, Bild V, The interdependence of the reactive species of oxygen, nitrogen, and carbon. J Physiol Biochem., 2013; 69(1): 147-154.

78. Ciobica A, Popescu R, Haulica I, Bild W, Aspects regarding the neurobiology of psycho-affective functions. J Med Biochem., 2012; 31(1): 83-87.

79. Valstad M, Alvares GA, Andreassen OA, Westlye LT, Quintana DS, The relationship between central and peripheral oxytocin concentrations: a systematic review and meta-analysis protocol. Syst Rev., 2016; 31(5): 49.

80. Mooney SJ, Douglas NR, Holmes MM, 1 Peripheral administration of Oxytocin increases social affiliation in the naked mole-rat (Heterocephalus glaber). Horm Behav., 2014; 65(4): 380-385.

81. Crine AF, Boulanger B, Nizet G, Effect of daily pretrial injection of Oxytocin on rat behavior in the open-field situation. Regul Pept., 1983; 5(2): 145-152.

82. Lancaster K, Carter CS, Pournajafi-Nazarloo H, Karaoli T, Lillard TS, Jack A, Davis JM, Morris J, Connelly JJ, Plasma Oxytocin explains individual differences in neural 8 substrates of social perception. Front Hum Neurosci., 2015; 9: 132.

83. Valstad M, Alvares GA, Andreassen OA, Westlye LT, Quintana DS, The relationship between central and peripheral Oxytocin concentrations: a systematic review and meta analysis protocol. Systemat Rev., 2016; 5: 49.

84. Zhong S, Monakhov M, Mok HP, Tong T, Lai PS, Chew SH, Ebstein RP, U-Shaped Relation between Plasma Oxytocin Levels and Behavior in the Trust Game. PLoS ONE, 2012; 14 7(12): e51095. 